OPEN ACCESS

Edited by:

Dingde Xu,

Sichuan Agricultural University, China

Reviewed by:

Wei Shui,

Fuzhou University, China

Shili Guo,

Southwestern University of Finance and Economics, China

Fangting Xie,

Jiangxi Agricultural University, China

Fang Su,

Shaanxi University of Science and

Technology, China

*Correspondence:

Jiquan Peng

pengjiquan@jxufe.edu.cn

Specialty section:

This article was submitted to

Environmental Informatics and Remote

Sensing,

a section of the journal

Frontiers in Environmental Science

Received: 18 December 2021

Accepted: 17 January 2022

Published: 10 February 2022

Citation:

Peng J, Zhao Z and Liu D (2022) Impact of Agricultural Mechanization on Agricultural Production, Income, and Mechanism: Evidence From Hubei

Province, China.

Front. Environ. Sci. 10:838686

doi: $10.3389 /$ fenvs.2022.838686

\section{Impact of Agricultural Mechanization on Agricultural Production, Income, and Mechanism: Evidence From Hubei Province, China}

\author{
Jiquan Peng *, Zihao Zhao and Dingning Liu \\ School of Economics, Jiangxi University of Finance and Economics, Nanchang, China
}

Increasing agricultural operating income is not only an important step in improving agricultural work for farmers in the new era, but is also a powerful way to promote rural revitalization. To improve our understanding of the high-quality development of agriculture in China, the factors limiting agricultural income and the impact of the level of agricultural mechanization on agricultural production and income and its mechanism were analysed. Based on field survey data on farmers, this study analysed the influence of agricultural mechanization level on agricultural production and income by utilizing a sample-modified endogenous merging model and a threshold effect model. The level of mechanization has a significant positive impact on the cost, output value, income and return rate of all types of crops. For every $1 \%$ increase in the level of mechanization, the yields of all crops, grain crops and cash crops increase by 1.2151, 1.5941 and $0.4351 \%$, respectively. Heterogeneity analysis shows that the level of mechanization has a certain threshold effect on income, with a greater effect occurring after the threshold. A test of action mechanism shows that the mechanization level can increase income via a factor intensification path and quality improvement path, with the partial mediation effects of the two paths being 28.8 and $27.4 \%$, respectively. It is recommended to increase subsidies to purchase agricultural machinery, research and promote machinery suitable for cash crops, increase the level of socialized agricultural services, and improve the ability of farmers to apply novel agricultural machinery and tools so as to increase their operating profits.

Keywords: agricultural mechanization level, agricultural production, agricultural income, ivtobit model, threshold effect model

\section{INTRODUCTION}

As China's agriculture is moving towards a high-quality development stage, it is necessary to focus on improving the quality and efficiency of agricultural production (Huang, 2021). For many years, the limited income obtainable from agriculture has greatly dampened the enthusiasm of agricultural labourers. Although agricultural subsidies, a protective minimum grain price and other relevant policies have guaranteed the income of agricultural workers to a certain extent, they have also aggravated the problems of inverted food prices at home and abroad and weak international competitiveness of agricultural products (Gao and Wang, 2021). For example, according to The National Data Collection of Cost and Income of Agricultural Products 2009, the average output of the top three grains (rice, wheat and corn) in 2008 was 11891.4 yuan per hectare and its average total 
cost was 9006.15 yuan per hectare. Hence, the net profit was 2885.25 yuan per hectare, a cost profit rate of $32.04 \%$. Ten years later in 2018, according to The National Agricultural Product Cost and Income.

Data Collection 2019, their average output value was 16175.4 yuan per hectare, the average total cost was 16633.35 yuan per hectare, the net profit was-457.95 yuan per hectare, and the cost profit rate was $-2.75 \%$. Hence, the net profit of grain has changed from positive to negative in the past 10 years, and agricultural operating income has been continuously compressed, mainly because the rate of growth in agricultural production costs has been much higher than that of output value. China's present agricultural development situation clearly shows that there is still much agricultural modernization that can be achieved (Peng et al., 2016; Jiang and Zhang, 2017). In the future, small farmers will still be the basic units of China's agricultural production and operation. Only by strengthening the connection between small farmers and modern agriculture can we achieve better agricultural modernization (Luo, 2020). Therefore, while improving the quality and efficiency of agricultural development, it is also necessary to continuously improve the confidence and enthusiasm of agricultural workers by increasing their income, which is also the basic aim of China's rural revitalization strategy. The fundamental reason for the backwardness of China's agriculture and rural modernization lies the low use of agricultural machinery, which inhibits the improvement of agricultural production efficiency and leads to unreasonable agricultural production structure and poor circulation of agricultural products market. This series of problems will inevitably affect the pace of agricultural modernization. Therefore, to accelerate the process of agricultural modernization in China, it is necessary to improve the agricultural technology adoption rate of farmers, especially the use of agricultural machinery, so as to improve agricultural production efficiency, create more agricultural surplus economy, increase the possibility of farmers' market participation, and than promot high-quality agricultural development.

\section{LITERATURE REVIEW AND THEORETICAL ANALYSIS}

\subsection{Related Literature Review}

The issue of agricultural operating income has always attracted much attention. Previous studies have mainly explored ways to improve agricultural operating income in the following aspects: 1) Agricultural land use. The loss of productivity due to land fragmentation will cause declines in agricultural profits ( $\mathrm{Lu}$ and $\mathrm{Hu}, 2015$; Wang and Tan, 2020). Increasing the scale of operation can reduce the cost of agricultural production and, thus, increase income (Zhang et al., 2018). Some scholars have tried to increase agricultural income by transferring land to expand the scale of farms (Xu et al., 2020; Yang et al., 2021). Peng et al. (2021a) found that land transfer can effectively lower agricultural production costs. Chen et al. (2014) found that the exogenous land transfer model has greater agricultural benefits than the endogenous land transfer model. Some scholars believe that land transfer cannot increase agricultural operating income but will instead reduce it due to excessively high turnover fees (Cai et al., 2015). 2) Input of factors of production. Sound agricultural infrastructure can promote the utilization of agricultural factors and income (Zeng and Li, 2015; Li et al., 2016). The availability of rural public goods and agricultural machinery can alleviate declines in operating income caused by rural aging (He et al., 2016; Yao et al., 2021). In addition, the use pesticides, agricultural films, fertilizer and division of labor also affect the agricultural per unit yield (Xiao et al., 2015; Yang and Liu, 2021; Ragasa and Chapoto, 2017), output value and profit, thereby affecting income.

3) Macro policies and institutions. She et al. (2013) found that the land transfer policy can increase the income of farmers, enterprises and the government. Zhou et al. (2017) found that policy subsidies are the main reason for the competitive price advantage of American sorghum. Liu and Wu (2019) found that inappropriate institutional arrangements lead to misallocation of agricultural land resources and reduced agricultural returns. Liu (2020) believes that collective ownership can provide equal land security for collective members, but that long-term contract relationships increase the intergenerational land interest inequality of farmers. Other perspectives also exist; for example, Chen (2019) found that the human capital of farmers increases agricultural operation income, while Lei et al. (2021) found that the internet increases the operating income of such farmers.

There has also been much research on the impact of agricultural machinery on agricultural production (Deng et al., 2020), which has two main aspects: cost savings and improvements in quality and efficiency. Firstly, rising labour costs are an important cause of the decline in agricultural profitability (Li et al., 2017). The service price of agricultural machinery is generally lower than labour costs (Tian et al., 2020). Farmers using agricultural machinery can significantly reduce labour costs (Yao, 2009; Luo and Qiu, 2021). Furthermore, agricultural machinery can perform land levelling and land preparation, which effectively improve the utilization rate of agricultural resources and reduce the need for weed and insect pest control (He et al., 2018; Nam et al., 2021). In addition, agricultural mechanization can also carry out combined fertilization and sowing, which not only ensures sowing accuracy but also reduces the cost of seeds and fertilizer (Liu and Zhou, 2018).

The second aspect is to improve quality and increase efficiency. Such improvements mainly include increased agricultural production and product quality. Agricultural machinery can perform the functions of levelling, land preparation, deep turning and deep scarification (Aslan et al., 2007), which can improve land quality better than the traditional manual and livestock operation methods, especially in the transformation of medium- and low-yield fields (Zhou et al., 2019; Peng and Zhang, 2020). Agricultural machinery can increase the degree of multiple cropping of cultivated land to provide the potential for multiple crop cycles per year, thus improving production capacity and land output rates (Peng et al., 2020; Ji et al., 2021). Mechanical irrigation and drainage, dry farming machinery and mechanical spraying can effectively mitigate risks such as drought, floods, weeds and insect pests (Berdnikova, 2018). Mechanical sowing and field management can make crop distributions more uniform and promote growth (Hu and Zhang, 2018), while the use of standardized agricultural 
machinery can reduce agricultural losses and improve product quality (Qu et al., 2021). In addition, the scale of land is an important factor restricting the adoption of agricultural machinery. The larger the operating area of farmers, the higher the Frontier of production, and the greater the role of agriculture in boosting agricultural output and increasing income (Chen, 2015).

Moreover, some studies have shown that the use of agricultural mechanization has an important impact on highquality agricultural development of agriculture. Liu et al. (2021) used the improved EBM model to measure and analyze the spatial and temporal evolution characteristics of agricultural equipment allocation efficiency in China, and found that the regional differences in agricultural equipment allocation efficiency were obvious, with central and eastern regions of China being higher than the national average and western regions consistently lower than the national average. The high-quality development of agriculture requires continuous improvement of the allocation efficiency of agricultural machinery and equipment, promoting cross-regional coordination and cooperation, and give play to the radiation-driven role of high-efficiency provinces and regions. Chen and Zhang (2021), Xu and Song (2021) believe that strengthening the promotion of advanced agricultural machinery technology is one of the ways to increase the level of green and high-quality agricultural development. Peng et al. (2020) found that agricultural mechanization can improve the level of comprehensive agricultural development by optimizing the agricultural planting structure. Tang et al. (2018) found that the use of agricultural machinery can reduce agricultural production losses, thereby reducing agricultural production costs and promoting the high-quality agricultural development.

There is abundant research on agricultural operating income, some from the perspective of agricultural machinery use. However, it has the following shortcomings. First, although the macro-level data used in existing research can estimate overall agricultural operating income, it is not conducive to analyze its mechanisms. For this, finer-scale farmer household data is more useful. Second, there are different scopes of research on agricultural operating income. Most scholars use indicators of output, output value, income and rate of return, and it is difficult to obtain a complete picture of agricultural operating income by such one-sided analyses. Furthermore, existing analyses do not consider the different effects of agricultural machinery efficiency on cash and food crops. Third, there may be measurement errors in previous analyses, and the threshold effects related to operational scale have not been considered. Based on this, this paper uses data from 1,116 farmers in Hubei Province, China, and IVTobit and threshold models to analyse the impact and mechanisms of agricultural mechanization on agricultural production and income. This provides a reference for the development of agricultural mechanization and income in China.

\subsection{Theoretical Analysis and Research Hypothesis}

\subsubsection{Factor Intensification Path}

The use of agricultural machinery can enhance the utilization rate of agricultural factors and reduce the cost of various agricultural production (Peng et al., 2020). The combined tillage technology with subsoiling as the main part is adopted in the field preparation before sowing, which can replace the traditional operations such as turning, harrowing, ridge raising, stubble planing, and base fertilizer application with only one mechanical operation, thus saving agricultural tools and labor input costs (He et al., 2018). Mechanical precision sowing technology is adopted in sowing process, which can effectively save seeds and reduce seed cost (Li et al., 2021). The use of mechanical deep fertilization technology in the fertilization process can apply the fertilizer required for crop production in a fixed proportion, quantitative, fixed position, fixed depth and fixed level to the plough layer soil, so as to avoid the waste of chemical fertilizer application (Ning et al., 2018). In addtion, higher quality seeds can lead to lower pesticide costs and obtain higher agricultural yields, as well as reduce environmental pollution and lower land restoration costs (Lu, 2014).

\subsubsection{Quality Improvement Path}

The functions of agricultural machinery for leveling the ground, deep ploughing and deep loosening can improve the quality of the land more than the traditional human and animal work, thereby maximizing the agricultural output (Zhou et al., 2019). Moreover, the land management area will affect the use of agricultural machinery, so that there are differences in the income increase of mechanical technological progress in different management areas (Peng J.Q. and Zhang L.G, 2020). The function of scrambling for planting and harvesting of agricultural machinery will promote the repeated planting of cultivated land and improve the comprehensive agricultural production capacity and land yield rate (Ji et al., 2021). Furthermore, agricultural machinery has the function of resisting disasters such as droughts and floods, weeds and pests, and mechanical seeding and field management can make crops evenly distributed and grow well (Hu and Zhang, 2018). Standardized agricultural machinery operation can also reduce agricultural losses and improve product quality ( $\mathrm{Li}$ et al., 2019). Agricultural machinery harvesting also allows early access to markets for agricultural products and higher agricultural yields at higher prices, thereby increasing agricultural operating income and contributing to poverty reduction (Peng et al., 2019). Based on the above theoretical analysis, this paper proposes the following research hypothesis:

Hypothesis 1: Agricultural mechanization can improve agricultural production and income.

Hypothesis 2: Agricultural mechanization has a threshold benefit on agricultural production and income, and has a greater impact on the agricultural operation income of various crops after the threshold.

Hypothesis 3: Agricultural mechanization may promote agricultural production and income through the factor intensification path and the quality improvement path. 


\section{MATERIALS AND METHODS}

\subsection{Sample and Data Source}

We used data from a field survey of households in Hubei Province conducted in 2018. The survey obtained the basic information of the household, its natural and physical assets, production and operating conditions, land transfer behaviour, and farmers' knowledge of policy. The research site was in Jianli and Qichun counties of Hubei Province, China, the terrain of the above two counties includes plains, hills and mountains, basically covering all the terrain and crop varieties of Hubei Province. The level of agricultural mechanization in these two counties is $66.75 \%$, which is basically consistent with the comprehensive mechanization level of cultivation, seeding and harvesting of major crops announced in Hubei Province, indicating that these two counties can represent the production of agriculture in Hubei Province to a certain extent. This survey adopted the method of random sampling to select the survey objects, involving 44 villages in 11 towns. There were 26 households investigated in each village, making a total of 1,144 households. After 28 invalid questionnaires were removed, a total of 1,116 valid samples were obtained.

\subsection{Definition of Variables}

\subsubsection{Agricultural Operating Income}

In this paper, agricultural operating income refers to the income obtained by farmers by cultivating land. It is mainly measured by the amount of income and rate of return, which are calculated by the net income per hectare and rate of return per hectare, respectively. In order to understand the structure of agricultural operating income sources, the output value and cost of agriculture were also investigated, which were calculated from the average agricultural output per hectare and the average agricultural cost per hectare, respectively. At the same time, considering the different influences of agricultural machinery on different crops, we also considered grain crops and cash crops separately.

\subsubsection{Agricultural Mechanization Level}

Researchers often measure the level of agricultural mechanization in terms of the total power of the machinery or its net value. These indicators are suitable for measuring the level of agricultural mechanization at the regional level but not at the farmer level. For this, it is more appropriate to use the calculation method of the Ministry of Agriculture and Rural Affairs, which is the weighted average of the machine farming rate, machine seeding rate and machine harvesting rate (with weights of $0.4,0.3$ and 0.3 , respectively) at the farmer level (Peng et al., 2021b). This index is not only easy to obtain but is also more accurate in measuring the machinery usage behaviour of farmers.

\subsubsection{Control Variables}

Education level per household member (Xu et al., 2019a). Families with higher education are better at improving their operating income via the rational allocation of resources. Average age of the family labour force (Xu et al., 2019b).
Agriculture is highly technical and requires experience, such that labourers with rich experience in farming gain greater benefits. Percentage of unhealthy people. Unhealthy people reduce the effective supply of family labour and also affect agricultural investment and income due to their high medical expenses. Average working hours of migrant workers. More time taken to travel to work reduces farming time and affects agricultural income (Liu et al., 2014). Area of farmland. More cultivated land resources allow greater economic benefits from agriculture. Farmland transfer-out area. The more land is transferred out, the lower the economies of scale. Proportion of farmland irrigation. More effectively irrigated farmland allows greater production and better management. Proportion of greenhouse area. As a form of protected agriculture, greenhouses can mitigate environmental risks and guarantee crop production, thereby guaranteeing income. Type of terrain. Plain areas provide better production and operating conditions than other areas, resulting in higher income.

\subsection{Descriptive Statistical Analysis}

Table 1shows the descriptive statistics of each variable, the total output value of agriculture is higher than the total agricultural cost, and the cost of cash crops is much higher than the cost of grain crops. The output value of grain crops is much higher than the output value of cash crops, which makes the profit and rate of return of grain crops higher than those of cash crops. The level of agricultural mechanization is $66.75 \%$, which is slightly lower than the comprehensive mechanization level of major crops reported for Hubei Province in 2018. The mean education level per household member is 6.3 years, indicating that most rural households have a low education level. The mean age of the family labour force is 40 years, indicating that the current rural labour force is generally comprised of older people. The mean percentage of unhealthy people is $12.73 \%$, which is a significant proportion. The mean working hours of migrant workers is 49 days with a large standard deviation, which indicates that there are large differences in labour force allocation among households. The average farmland area is $0.375 \mathrm{hm}^{2}$, and the average transfer-out area is $0.027 \mathrm{hm}^{2}$. The average proportion of farmland irrigation is $35.83 \%$, indicating that the effective irrigated area still needs to be improved. The average proportion of greenhouse area is 0.1 , which indicates that built-up agriculture is not yet popular in rural areas. The mean terrain type value is 0.33 , indicating that $1 / 3$ of the sample was in a plain area. The mean level of household savings is 9.429 , indicating that the average savings of each family is 12,444 yuan.

\subsection{Model}

The model used to investigate the impact of agricultural mechanization on income can be written as:

$$
Y_{\mathrm{i}}=\alpha_{0}+\beta_{0} x_{i}+\sum \delta_{i} C_{i}+\mu_{i},
$$

Where $\mathrm{i}$ denotes farmers and $Y_{i}$ is an explanatory variable that includes the cost, output value, profit and rate of return per hectares for the total crop, grain crop and cash crop. $x_{i}$ refers to 
TABLE 1 | Descriptive statistics of the data used in this study.

\begin{tabular}{|c|c|c|c|c|c|}
\hline Variable (units) & Description & Mean & SD & Min & Max \\
\hline Total cost (yuan) & Total cost of agriculture (actual value takes the logarithm) & 7.686 & 1.084 & 0 & 11.51 \\
\hline Grain crops cost (yuan) & Cost of grain crops (actual value takes the logarithm) & 3.757 & 2.904 & 0 & 10.80 \\
\hline Cash crops cost (yuan) & Cost of cash crops (actual value takes the logarithm) & 3.929 & 1.333 & 0 & 10.11 \\
\hline Total output (yuan) & Total output value of agriculture (actual value takes the logarithm) & 8.376 & 0.902 & 0 & 13.22 \\
\hline $\begin{array}{l}\text { Grain crops output } \\
\text { (yuan) }\end{array}$ & Output value of grain crops (actual value takes the logarithm) & 4.239 & 1.471 & 0 & 12.18 \\
\hline $\begin{array}{l}\text { Cash crops output } \\
\text { (yuan) }\end{array}$ & Output value of cash crops (actual value takes the logarithm) & 4.137 & 3.661 & 0 & 12.41 \\
\hline Total profit (yuan) & Total profit of agriculture (actual value takes the logarithm) & 0.690 & 2.957 & 0 & 1.64 \\
\hline Grain crops profit (yuan) & Profit of grain crops (actual value takes the logarithm) & 0.482 & 1.471 & 0 & 1.18 \\
\hline Cash crops profit (yuan) & Profit of cash crops (actual value takes the logarithm) & 0.208 & 3.316 & 0 & 1.06 \\
\hline Total return rate & Total agricultural rate of return (total profit divided by total cost) & 0.181 & 0.146 & 0 & 0.23 \\
\hline Grain crops return rate & Rate on return of grain crops (grain crop profit divided by cost) & 0.128 & 0.513 & 0 & 0.15 \\
\hline Cash crops return rate & Rate of return on cash crops (cash crop profit divided by cost) & 0.053 & 0.163 & 0 & 0.11 \\
\hline Machine & $\begin{array}{l}\text { Level of agricultural mechanization (sum of machine harvesting rate } \times 0.4 \text {, machine seeding and farming } \\
\text { rates } \times 0.3 \text { ) }\end{array}$ & 0.668 & 0.202 & 0 & 1 \\
\hline Education (years) & Education level per household member (total years of education divided by number of household members) & 6.335 & 2.555 & 0 & 13.50 \\
\hline Age & Average age of family labour force (total age of labour force divided by number of labourers) & 40.193 & 9.860 & 14.29 & 64.67 \\
\hline Healthy & Percentage of unhealthy people (unhealthy people divided by number of householders) & 0.127 & 0.272 & 0 & 1 \\
\hline Migrant (days) & Average working hours of migrant workers (total working hours divided by number of householders) & 49.02 & 2.140 & 0 & 240 \\
\hline Land $\left(\mathrm{hm}^{2}\right)$ & Area of farmland (actual value) & 0.375 & 3.931 & 0 & 1.633 \\
\hline Transfer $\left(\mathrm{hm}^{2}\right)$ & Transfer-out area of farmland (actual value) & 0.027 & 1.730 & 0 & 1 \\
\hline Irrigate & Proportion of irrigated farmland (effective irrigated area divided by total farmland area) & 0.358 & 0.425 & 0 & 1 \\
\hline Facility & Proportion of greenhouse area (greenhouse area divided by farmland area) & 0.101 & 1.024 & 0 & 1 \\
\hline Terrain & Type of terrain ( 1 = plain; 0 = non-plain) & 0.335 & 0.472 & 0 & 1 \\
\hline Village mechanization & Level of agricultural mechanization at the village level (actual value) & 0.670 & 0.028 & 0.55 & 0.75 \\
\hline Income (yuan) & Level of household savings (actual value takes the logarithm) & 9.429 & 1.358 & 0 & 11.51 \\
\hline Factor & Utilization rate of agricultural factors (agricultural output divided by agricultural cost) & 1.199 & 0.783 & 0 & 5.81 \\
\hline Price (yuan) & Average price of agricultural products (actual value) & 1.186 & 0.798 & 0 & 5.5 \\
\hline
\end{tabular}

the level of agricultural mechanization, $C_{i}$ is a control variable, $\mu_{i}$ is random perturbation term, and $\alpha_{0}, \beta_{0}$ and $\delta_{\mathrm{i}}$ are parameters to be estimated.

There may be a mutual, causal, endogenous relationship between the level of agricultural mechanization and income. Increased mechanization may increase returns, which gives farmers more capital to use machinery. In addition, some unobservable economic variables at the village level may also affect farming income, leading to the problem of model endogeneity due to omitted variables. This article adopts the instrumental variable method to solve this problem. In Eq. 2, the endogenous variable is machine , $_{i}$ and the first stage of estimation by two-stage least-squares (2SLS) is:

$$
\text { machine }_{i}=\gamma_{1} Z_{i}+\gamma_{2} C_{i}+\varepsilon_{i},
$$

Where $Z_{i}$ is a set of instrumental variables and $\varepsilon_{i}$ is a random error term.

In this paper, two instrumental variables are selected. One is the level of household savings. As the use of agricultural machinery costs money, households with more savings are better able to use it, and household savings do not affect agricultural income. therefore, the level of household savings satisfies the requirement of exogeneity of the instrumental variable. The second is the level of agricultural mechanization at the village level. When micro-level data analysis is adopted, data aggregated at the regional level can be used to calculate the instrumental variables of the model (Cadr and Krueger, 1996; Staiger and Stock, 1997). This paper used the level of agricultural mechanization at the village level as the instrumental variable. Generally speaking, this variable will not affect the income of a single family, but may affect the probability of a single farmer using agricultural machinery. When the level of agricultural mechanization in the village is high, individual farmers have greater probability of using agricultural machinery. thus, the level of mechanization at the village level also satisfies the exogeneity of the instrumental variables.

Considering that there are more instrumental variables than endogenous ones, it is necessary to carry out over-identified tests and weak instruments tests on the instrumental variables used in this model to ensure their validity.

A Tobit model was also used to solve the problem of sample selection bias that may appear in the model. Its expression is as follows:

$$
\begin{gathered}
Y_{i}^{*}=\alpha_{0}+\beta_{0} x_{i}+\sum \delta_{i} C_{i}+\mu_{i}, \\
\left\{\begin{array}{l}
Y_{i}=Y_{i}^{*}, \quad \text { if } Y_{i}^{*}>0 \\
Y_{i}=0, \text { if } Y_{i}^{*} \leq 0,
\end{array}\right.
\end{gathered}
$$

To ensure that the real impact of the level of mechanization on operating income can be estimated, it is necessary to solve both the endogeneity and sample selection bias problems mentioned above. For this, a sample-corrected 2SLS estimation method, the 
TABLE 2 | OLS estimation of the impact of agricultural mechanization level on agricultural cost and output value.

\begin{tabular}{|c|c|c|c|c|c|c|}
\hline \multirow[t]{2}{*}{ Variable } & \multirow{2}{*}{$\begin{array}{l}\text { Total cost } \\
\text { (1) }\end{array}$} & \multirow{2}{*}{$\begin{array}{l}\text { Grain crop } \\
\text { cost } \\
(2)\end{array}$} & \multirow{2}{*}{$\begin{array}{c}\begin{array}{c}\text { Cash crop } \\
\text { cost }\end{array} \\
\text { (3) }\end{array}$} & \multirow{2}{*}{$\frac{\text { Total output }}{\text { (4) }}$} & \multirow{2}{*}{$\begin{array}{c}\begin{array}{c}\text { Grain crop } \\
\text { output }\end{array} \\
(5)\end{array}$} & \multirow{2}{*}{$\begin{array}{c}\begin{array}{c}\text { Cash crop } \\
\text { output }\end{array} \\
\text { (6) }\end{array}$} \\
\hline & & & & & & \\
\hline \multirow[t]{2}{*}{ Machine } & $0.323^{\star \star \star}$ & $0.273^{\star \star \star}$ & $2.183^{\star \star \star}$ & $1.813^{\star \star \star}$ & $4.737^{\star \star \star}$ & $1.597^{\star \star \star}$ \\
\hline & (0.063) & $(0.518)$ & $(0.518)$ & $(0.445)$ & $(0.324)$ & $(0.403)$ \\
\hline \multirow[t]{2}{*}{ Education } & $-0.033^{\star \star \star}$ & $-0.031^{\star \star}$ & $-0.042^{\star}$ & $0.071^{\star}$ & $0.096^{\star \star \star}$ & 0.068 \\
\hline & $(0.006)$ & (0.015) & $(0.022)$ & $(0.039)$ & $(0.033)$ & $(0.044)$ \\
\hline \multirow[t]{2}{*}{ Age } & $-0.003^{\star \star \star}$ & -0.001 & $-0.027^{\star \star}$ & $0.015^{\star}$ & $0.016^{\star \star}$ & $0.015^{\star}$ \\
\hline & (0.001) & $(0.004)$ & (0.010) & $(0.008)$ & $(0.007)$ & $(0.009)$ \\
\hline \multirow[t]{2}{*}{ Healthy } & $0.240^{\star \star \star}$ & $0.252^{\star \star}$ & 0.307 & $-0.698^{\star}$ & $-1.062^{\star \star \star}$ & $-0.604^{\star \star}$ \\
\hline & $(0.053)$ & $(0.117)$ & $(0.434)$ & $(0.377)$ & $(0.331)$ & (0.293) \\
\hline \multirow[t]{2}{*}{ Migrant } & $0.014^{\star \star}$ & 0.009 & $0.037^{*}$ & $-0.072^{\star}$ & $-0.092^{\star \star}$ & -0.033 \\
\hline & $(0.006)$ & $(0.012)$ & $(0.020)$ & $(0.037)$ & $(0.044)$ & $(0.047)$ \\
\hline \multirow[t]{2}{*}{ Land } & $-0.002^{\star \star \star}$ & $-0.002^{\star \star}$ & $-0.015^{\star \star}$ & $0.021^{\star \star \star}$ & $0.022^{\star \star}$ & $0.021^{\star \star}$ \\
\hline & (0.001) & (0.001) & $(0.007)$ & (0.005) & (0.011) & $(0.010)$ \\
\hline \multirow[t]{2}{*}{ Transfer } & $0.014^{\star \star}$ & 0.005 & $0.160^{\star \star}$ & $-0.120^{\star \star \star}$ & $-0.196^{\star \star \star}$ & $-.119^{\star \star \star}$ \\
\hline & $(0.007)$ & $(0.014)$ & $(0.075)$ & (0.024) & $(0.024)$ & $(0.019)$ \\
\hline \multirow[t]{2}{*}{ Irrigate } & $-0.146^{\star \star \star}$ & $-0.215^{\star \star \star}$ & $-1.558^{\star \star \star}$ & $1.379^{\star \star \star}$ & $1.125^{\star \star \star}$ & $0.389^{\star \star}$ \\
\hline & (0.0375) & $(0.057)$ & (0.373) & $(0.369)$ & $(0.315)$ & $(0.176)$ \\
\hline \multirow[t]{2}{*}{ Facility } & $-0.023^{\star \star \star}$ & $-0.024^{\star \star}$ & $-0.243^{\star \star \star}$ & $0.393^{\star \star \star}$ & $0.544^{\star \star \star}$ & $0.338^{\star \star}$ \\
\hline & (0.008) & $(0.011)$ & (0.073) & $(0.106)$ & (0.088) & $(0.155)$ \\
\hline \multirow[t]{2}{*}{ Terrain } & $-0.725^{\star \star \star}$ & $-0.684^{\star \star \star}$ & $-0.870^{\star \star}$ & $0.477^{*}$ & $1.834^{\star \star *}$ & 0.280 \\
\hline & (0.039) & (0.183) & $(0.372)$ & (0.265) & (0.233) & $(0.211)$ \\
\hline \multirow[t]{2}{*}{ Constant } & $5.237^{\star \star \star}$ & $4.132^{\star \star \star}$ & $5.517^{\star \star \star}$ & $2.367^{\star \star \star}$ & $5.214^{\star \star \star}$ & $1.682^{\star \star \star}$ \\
\hline & (0.195) & $(0.656)$ & (0.072) & $(0.520)$ & $(0.439)$ & $(0.566)$ \\
\hline$R^{2}$ & 0.086 & 0.136 & 0.098 & 0.142 & 0.398 & 0.078 \\
\hline
\end{tabular}

***, **, and * denote significance at the 1, 5 and 10\% levels, respectively.

TABLE 3 | OLS estimation of the influence of agricultural mechanization level on agricultural profit and rate of return.

\begin{tabular}{|c|c|c|c|c|c|c|}
\hline \multirow[t]{2}{*}{ Variable } & Total profit & $\begin{array}{c}\text { Grain crop } \\
\text { profit }\end{array}$ & $\begin{array}{c}\text { Cash crop } \\
\text { profit }\end{array}$ & $\begin{array}{c}\text { Total return } \\
\text { rate }\end{array}$ & $\begin{array}{l}\text { Grain crop } \\
\text { return rate }\end{array}$ & $\begin{array}{l}\text { Cash crop } \\
\text { return rate }\end{array}$ \\
\hline & (1) & (2) & (3) & (4) & (5) & (6) \\
\hline Machine & $\begin{array}{l}1.597^{\star \star \star} \\
(0.403)\end{array}$ & $\begin{array}{c}2.079^{\star \star \star} \\
(0.327)\end{array}$ & $\begin{array}{c}1.476^{\star \star \star} \\
(0.562)\end{array}$ & $\begin{array}{l}0.364^{\star *} \\
(0.155)\end{array}$ & $\begin{array}{c}0.389^{\star \star \star} \\
(0.040)\end{array}$ & $\begin{array}{l}0.279^{\star \star} \\
(0.110)\end{array}$ \\
\hline Education & $\begin{array}{l}0.071^{\star} \\
(0.039)\end{array}$ & $\begin{array}{l}0.074^{\star \star} \\
(0.030)\end{array}$ & $\begin{array}{l}0.066^{\star} \\
(0.037)\end{array}$ & $\begin{array}{c}0.0124^{\star *} \\
(0.006)\end{array}$ & $\begin{array}{c}0.014^{\star \star \star} \\
(0.001)\end{array}$ & $\begin{array}{l}0.010^{\star \star} \\
(0.005)\end{array}$ \\
\hline Age & $\begin{array}{l}0.015^{\star} \\
(0.008)\end{array}$ & $\begin{array}{c}0.017^{\star \star \star} \\
(0.006)\end{array}$ & $\begin{array}{l}0.014^{\star} \\
(0.008)\end{array}$ & $\begin{array}{c}0.013^{\star \star \star} \\
(0.002)\end{array}$ & $\begin{array}{c}0.020^{\star \star \star} \\
(0.001)\end{array}$ & $\begin{array}{c}0.012^{\star \star \star} \\
(0.002)\end{array}$ \\
\hline Healthy & $\begin{array}{c}-1.062^{\star \star \star} \\
(0.331)\end{array}$ & $\begin{array}{c}-1.186^{\star \star \star} \\
(0.253)\end{array}$ & $\begin{array}{c}-0.919^{\star \star} \\
(0.407)\end{array}$ & $\begin{array}{c}-0.168^{\star \star} \\
(0.076)\end{array}$ & $\begin{array}{c}-0.121^{\star \star \star} \\
(0.009)\end{array}$ & $\begin{array}{l}-0.111^{*} \\
(0.062)\end{array}$ \\
\hline Migrant & $\begin{array}{c}-0.092^{\star \star} \\
(0.044)\end{array}$ & $\begin{array}{c}-0.114^{\star \star \star} \\
(0.038)\end{array}$ & $\begin{array}{l}-0.014 \\
(0.053)\end{array}$ & $\begin{array}{c}-0.025^{\star \star} \\
(0.011)\end{array}$ & $\begin{array}{c}-0.030^{\star \star \star} \\
(0.002)\end{array}$ & $\begin{array}{c}-0.020^{\star} \\
(0.011)\end{array}$ \\
\hline Land & $\begin{array}{c}0.021^{\star \star \star} \\
(0.005)\end{array}$ & $\begin{array}{c}0.032^{\star \star \star} \\
(0.004)\end{array}$ & $\begin{array}{l}0.011^{\star *} \\
(0.004)\end{array}$ & $\begin{array}{l}0.005^{\star} \\
(0.003)\end{array}$ & $\begin{array}{l}0.005^{\star \star} \\
(0.001)\end{array}$ & $\begin{array}{c}0.003^{\star \star \star} \\
(0.001)\end{array}$ \\
\hline Transfer & $\begin{array}{c}-0.110^{\star \star \star} \\
(0.024)\end{array}$ & $\begin{array}{c}-0.210^{\star \star \star} \\
(0.024)\end{array}$ & $\begin{array}{c}-0.082^{\star \star \star} \\
(0.027)\end{array}$ & $\begin{array}{c}-0.015^{\star \star} \\
(0.007)\end{array}$ & $\begin{array}{c}-0.020^{\star \star \star} \\
(0.001)\end{array}$ & $\begin{array}{c}-0.013^{\star} \\
(0.008)\end{array}$ \\
\hline Irrigate & $\begin{array}{l}1.125^{\star \star \star} \\
(0.315)\end{array}$ & $\begin{array}{c}1.515^{\star \star \star} \\
(0.323)\end{array}$ & $\begin{array}{l}1.010^{\star \star} \\
(0.496)\end{array}$ & $\begin{array}{l}0.197^{\star \star \star} \\
(0.061)\end{array}$ & $\begin{array}{c}0.207^{\star \star \star} \\
(0.039)\end{array}$ & $\begin{array}{l}0.114^{*} \\
(0.062)\end{array}$ \\
\hline Facility & $\begin{array}{l}0.393^{\star \star \star} \\
(0.106)\end{array}$ & $\begin{array}{c}0.546^{\star \star \star} \\
(0.109)\end{array}$ & $\begin{array}{c}0.250^{\star \star \star} \\
(0.029)\end{array}$ & $\begin{array}{c}0.067^{\star \star \star} \\
(0.018)\end{array}$ & $\begin{array}{l}0.124^{\star \star} \\
(0.057)\end{array}$ & $\begin{array}{c}0.065^{\star \star \star} \\
(0.023)\end{array}$ \\
\hline Terrain & $\begin{array}{l}1.834^{\star \star \star} \\
(0.233)\end{array}$ & $\begin{array}{c}2.017^{\star \star \star} \\
(0.281)\end{array}$ & $\begin{array}{l}1.008^{\star \star \star} \\
(0.185)\end{array}$ & $\begin{array}{c}0.228^{\star \star \star} \\
(0.056)\end{array}$ & $\begin{array}{c}0.285^{\star \star \star} \\
(0.056)\end{array}$ & $\begin{array}{l}0.015^{\star \star} \\
(0.007)\end{array}$ \\
\hline Constant & $\begin{array}{l}0.787^{\star \star} \\
(0.392)\end{array}$ & $\begin{array}{c}2.367^{\star \star \star} \\
(0.520)\end{array}$ & $\begin{array}{l}0.682^{\star \star} \\
(0.304)\end{array}$ & $\begin{array}{c}0.710^{\star \star \star} \\
(0.140)\end{array}$ & $\begin{array}{c}0.810^{\star \star \star} \\
(0.018)\end{array}$ & $\begin{array}{c}0.348^{\star \star \star} \\
(0.119)\end{array}$ \\
\hline $\mathrm{R} 2$ & 0.142 & 0.186 & 0.081 & 0.098 & 0.408 & 0.072 \\
\hline
\end{tabular}

*****, and * denote significance at the 1, 5 and 10\% levels, respectively. 
sample-corrected endogenous merging model (IVTobit), can be used with the following steps:

In the first stage, the residual term $\hat{\omega}_{i}$ is estimated using the Tobit model with $Y_{i}$ as the dependent variable and $C_{i}$ and $Z_{i}$ as the independent variables. Then, it is brought into Eq. 1 to obtain:

$$
Y_{i}=\alpha_{0}+\beta_{0} x_{i}+\sum \delta_{i} C_{i}+\beta_{1} \hat{\omega}_{i}+\varphi_{i}
$$

In the second stage, the 2SLS regression of Eq. 5 with $Z_{i}$ as the dependent variable is a non-zero sample, and the required estimated parameters can be obtained.

\section{EMPIRICAL RESULTS}

1. Benchmark Regression of the Impact of Agricultural Mechanization Level on Agricultural Operating Income

To analyse the impact of agricultural mechanization level on agricultural operating income in detail, this paper set dependent variables from a cost-benefit perspective. The dependent variables in columns 1) to 3) in Table 2 are total agricultural cost, grain crop cost and cash crop cost, and the dependent variables in columns 4) to 6) are total agricultural output value, grain crop output value and cash crop output value, respectively. The dependent variables in columns 1) to 3) in Table 3 are total agricultural profit, total grain crop profit and total cash crop profit, and the dependent variables in columns 4) to 6) are total agricultural rate of return, rate of return of grain crops and rate of return of cash crops, respectively.

The cost-regression model indicates that the level of agricultural mechanization has a significant positive impact on all types of agricultural costs, indicating that increases in mechanization increase the cost of production, with the increase in the cost of cash crops being the greatest. Each unit increase in the level of agricultural mechanization increases the costs of grain and cash crops by 0.273 and 2.183 units, respectively. The possible reason is that the more complicated operation and higher cost of using machinery for cash crops, and it is more difficult to exert its scale effect than grain crops, resulting in increasing their production cost. In terms of control variables, the education level per member of household, average age of family labour force, area of farmland, proportion of farmland irrigation, proportion of greenhouse area, and type of the terrain all have significant negative impacts on various types of agricultural costs, with a greater impact on the cost of cash crops. The percentage of unhealthy people, average working hours of migrant workers and transfer-out area of farmland all have significant positive impacts on all types of agricultural costs and have the greatest effect on the cost of cash crops.

From the regression model of output value, the level of agricultural mechanization has a significant positive impact on various agricultural output values, indicating that the use of agricultural machinery can indeed improve the production efficiency of crops. For every 1 unit increase in the level of agricultural mechanization, the total agricultural output value, grain crop output value and cash crop output value increase by $1.813,4.737$ and 1.597 units, respectively. The use of agricultural machinery has the greatest impact on grain crop output; it is likely influenced by the economies of scale, since grain crops are planted on a larger scale than cash crops. In terms of control variables, the percentage of unhealthy people, average working hours of migrant workers and transfer-out area of farmland all have significant negative impacts on the output value of each type of agriculture. The education lever per member of household, the average age of family labour force, the area of farmland, the proportion of farmland irrigation, the proportion of greenhouse area, and the type of the terrain all have significant positive impacts on the output value of each type of agriculture, and all of them have the greatest effect on the output value of grain crops.

Table 3 shows the results of the baseline regression of agricultural mechanization level on various types of agricultural profit and rates of return. The dependent variables in columns 1) to 3) are total agricultural profit, grain crop profit and cash crop profit, and in columns 4) to 6) they are total agricultural rate of return, rate of return of grain crops and rate of return of cash crops, respectively.

From the regression model of profit, the level of agricultural mechanization has a significant positive impact on the income of each type of agriculture and, for each unit increase in the level of agricultural mechanization, the total agricultural profit, profit of grain crops, and profit of cash crops increase by 1.597, 2.079 and 1.476 units, respectively, indicating that agricultural machinery can significantly increase the income of agricultural operations, with the greatest increase being for grain crops. This may be due to the differential effects of agricultural machinery on the income obtainable from cash crops and grain crops. The regression above shows that agricultural machinery is more likely to increase the cost of cash crops, but to a lesser degree than grain crops. The combined effect of these two aspects leads to greater income as agricultural machinery allows the expansion of grain crops. The direction of influence of the estimated coefficients of the control variables is also largely consistent with that of the output value regression model. From the regression model of rate of return, the level of agricultural mechanization has a significant positive effect on the income rate of each type of agriculture, with each unit increase in the level of mechanization increasing the total agricultural rate of return, rate of return of grain crops, and rate of return of cash crops by $0.364,0.389$ and 0.279 units, respectively. This indicates that the use of agricultural machinery is more likely to increase the income from grain crops. The direction of influence of the estimated coefficients of the control variables is also basically the same as that of the income value regression model and will not be repeated.

\section{Endogeneity Test of the Regression Model}

To resolve the possible sample selection errors and endogenous problems in the model, the instrumental variables, level of household savings and level of agricultural mechanization at the village level were brought into the IVTobit model. The results of the regressions are shown in Tables 4, 5; the first stages of the IVTobit regressions are excluded to save space. 
TABLE 4 | IVTobit estimation of the impact of agricultural mechanization level on cost and output.

\begin{tabular}{|c|c|c|c|c|c|c|}
\hline \multirow[t]{2}{*}{ Variable } & Total cost & $\begin{array}{c}\text { Grain crop } \\
\text { cost }\end{array}$ & $\begin{array}{c}\text { Cash crop } \\
\text { cost }\end{array}$ & Total output & $\begin{array}{c}\text { Grain crop } \\
\text { output }\end{array}$ & $\begin{array}{c}\text { Cash crop } \\
\text { output }\end{array}$ \\
\hline & (1) & (2) & (3) & (4) & (5) & (6) \\
\hline Machine & $\begin{array}{c}0.738^{\star \star \star} \\
(0.088)\end{array}$ & $\begin{array}{l}0.548^{\star \star \star} \\
(0.089)\end{array}$ & $\begin{array}{l}5.51^{\star \star \star} \\
(0.974)\end{array}$ & $\begin{array}{l}5.479^{\star \star} \\
(2.275)\end{array}$ & $\begin{array}{l}8.543^{\star \star} \\
(3.877)\end{array}$ & $\begin{array}{l}2.521^{\star} \\
(1.294)\end{array}$ \\
\hline Education & $\begin{array}{c}-0.043^{\star \star \star} \\
(0.006)\end{array}$ & $\begin{array}{c}-0.038^{\star \star} \\
(0.017)\end{array}$ & $\begin{array}{c}-0.087^{\star \star \star} \\
(0.025)\end{array}$ & $\begin{array}{l}0.121^{\star} \\
(0.066)\end{array}$ & $\begin{array}{l}0.184^{\star} \\
(0.110)\end{array}$ & $\begin{array}{l}0.041^{\star} \\
(0.025)\end{array}$ \\
\hline Age & $\begin{array}{c}-0.004^{\star \star \star} \\
(0.001)\end{array}$ & $\begin{array}{l}-0.001 \\
(0.004)\end{array}$ & $\begin{array}{c}-0.040^{\star \star} \\
(0.018)\end{array}$ & $\begin{array}{l}0.009^{\star \star} \\
(0.004)\end{array}$ & $\begin{array}{l}0.039^{\star} \\
(0.022)\end{array}$ & $\begin{array}{l}0.007^{\star} \\
(0.004)\end{array}$ \\
\hline Healthy & $\begin{array}{c}0.766^{\star \star \star} \\
(0.074)\end{array}$ & $\begin{array}{l}0.516^{\star \star} \\
(0.211)\end{array}$ & $\begin{array}{l}1.186^{\star \star \star} \\
(0.311)\end{array}$ & $\begin{array}{c}-1.198^{\star \star \star} \\
(0.352)\end{array}$ & $\begin{array}{c}-1.615^{\star \star \star} \\
(0.605)\end{array}$ & $\begin{array}{c}-0.594^{*} \\
(0.310)\end{array}$ \\
\hline Migrant & $\begin{array}{c}0.024^{\star \star \star} \\
(0.006)\end{array}$ & $\begin{array}{c}0.049^{\star \star \star} \\
(0.007)\end{array}$ & $\begin{array}{l}0.012^{*} \\
(0.007)\end{array}$ & $\begin{array}{c}-0.161^{\star \star} \\
(0.081)\end{array}$ & $\begin{array}{c}-0.244^{\star \star \star} \\
(0.032)\end{array}$ & $\begin{array}{l}-0.012 \\
(0.035)\end{array}$ \\
\hline Land & $\begin{array}{c}-0.005^{\star} \\
(0.003)\end{array}$ & $\begin{array}{c}-0.002^{\star \star} \\
(0.001)\end{array}$ & $\begin{array}{c}-0.039^{\star \star \star} \\
(0.004)\end{array}$ & $\begin{array}{l}0.021^{\star \star} \\
(0.010)\end{array}$ & $\begin{array}{c}0.037^{\star \star \star} \\
(0.009)\end{array}$ & $\begin{array}{l}0.009^{\star \star} \\
(0.004)\end{array}$ \\
\hline Transfer & $\begin{array}{l}0.014^{\star} \\
(0.008)\end{array}$ & $\begin{array}{c}0.003 \\
(0.029)\end{array}$ & $\begin{array}{l}0.288^{\star \star} \\
(0.108)\end{array}$ & $\begin{array}{c}-0.257^{\star \star \star} \\
(0.086)\end{array}$ & $\begin{array}{c}-0.798^{\star \star \star} \\
(0.253)\end{array}$ & $\begin{array}{l}-0.088 \\
(0.057)\end{array}$ \\
\hline Irrigate & $\begin{array}{c}-0.315^{\star \star \star} \\
(0.062)\end{array}$ & $\begin{array}{c}-0.243^{\star \star \star} \\
(0.007)\end{array}$ & $\begin{array}{c}-4.004^{\star \star \star} \\
(1.206)\end{array}$ & $\begin{array}{l}1.008^{\star \star \star} \\
(0.306)\end{array}$ & $\begin{array}{c}5.735^{\star \star \star} \\
(1.608)\end{array}$ & $\begin{array}{c}0.831^{\star \star \star} \\
(0.237)\end{array}$ \\
\hline Facility & $\begin{array}{c}-0.032^{\star \star \star} \\
(0.009)\end{array}$ & $\begin{array}{c}-0.028^{\star \star \star} \\
(0.009)\end{array}$ & $\begin{array}{c}-1.243^{\star \star \star} \\
(0.074)\end{array}$ & $\begin{array}{c}0.491^{\star \star \star} \\
(0.158)\end{array}$ & $\begin{array}{l}1.141^{\star \star \star} \\
(0.315)\end{array}$ & $\begin{array}{c}0.196^{\star \star \star} \\
(0.054)\end{array}$ \\
\hline Terrain & $\begin{array}{c}-0.241^{\star \star \star} \\
(0.014)\end{array}$ & $\begin{array}{c}-0.144^{\star \star \star} \\
(0.050)\end{array}$ & $\begin{array}{c}-2.902^{\star \star} \\
(1.147)\end{array}$ & $\begin{array}{c}2.955^{\star \star \star} \\
(0.945)\end{array}$ & $\begin{array}{c}3.388^{\star \star \star} \\
(0.550)\end{array}$ & $\begin{array}{l}1.305^{\star \star \star} \\
(0.195)\end{array}$ \\
\hline Constant & $\begin{array}{c}5.415^{\star \star \star} \\
(0.196)\end{array}$ & $\begin{array}{c}4.320^{\star \star \star} \\
(0.625)\end{array}$ & $\begin{array}{c}6.159^{\star \star \star} \\
(0.568)\end{array}$ & $\begin{array}{l}5.621^{\star \star \star} \\
(1.346)\end{array}$ & $\begin{array}{c}5.947^{\star \star \star} \\
(2.157)\end{array}$ & $\begin{array}{c}4.984^{\star \star \star} \\
(0.718)\end{array}$ \\
\hline
\end{tabular}

***, **, and * denote significance at the 1, 5 and 10\% levels, respectively.

TABLE 5 | IVTobit estimation of the impact of agricultural mechanization on agricultural profit and rate of return.

\begin{tabular}{|c|c|c|c|c|c|c|}
\hline \multirow[t]{2}{*}{ Variable } & Total profit & $\begin{array}{c}\text { Grain crop } \\
\text { profit }\end{array}$ & $\begin{array}{c}\text { Cash crop } \\
\text { profit }\end{array}$ & $\begin{array}{l}\text { Total return } \\
\text { rate }\end{array}$ & $\begin{array}{l}\text { Grain crop } \\
\text { return rate }\end{array}$ & $\begin{array}{l}\text { Cash crop } \\
\text { return rate }\end{array}$ \\
\hline & (1) & (2) & (3) & (4) & (5) & (6) \\
\hline \multirow[t]{2}{*}{ Machine } & $3.143^{\star \star}$ & $5.479^{\star \star}$ & $1.694^{\star \star \star}$ & $1.215^{\star}$ & $1.594^{\star \star \star}$ & $0.435^{\star}$ \\
\hline & $(1.356)$ & $(2.275)$ & $(0.617)$ & $(0.696)$ & $(0.492)$ & $(0.247)$ \\
\hline \multirow[t]{2}{*}{ Education } & $0.121^{\star}$ & $0.211^{\star \star \star}$ & $0.030^{\star}$ & $0.033^{\star \star \star}$ & $0.041^{\star \star \star}$ & $0.020^{\star}$ \\
\hline & $(0.066)$ & $(0.022)$ & $(0.045)$ & (0.013) & (0.002) & $(0.011)$ \\
\hline \multirow[t]{2}{*}{ Age } & $0.019^{\star \star \star}$ & $0.027^{\star \star \star}$ & $0.013^{\star}$ & $0.021^{\star \star *}$ & $0.0315^{\star \star \star}$ & $-0.013^{\star \star \star}$ \\
\hline & (0.004) & $(0.004)$ & $(0.007)$ & (0.003) & (0.001) & (0.002) \\
\hline \multirow[t]{2}{*}{ Healthy } & $-1.615^{\star \star \star}$ & $-2.312^{\star \star \star}$ & $-0.235^{\star}$ & $-0.253^{\star \star}$ & $-0.421^{\star \star \star}$ & $-0.176^{\star}$ \\
\hline & (0.605) & $(0.142)$ & $(0.137)$ & (0.108) & (0.009) & $(0.097)$ \\
\hline \multirow[t]{2}{*}{ Migrant } & $-0.161^{\star \star}$ & $-0.233^{\star \star \star}$ & -0.015 & $-0.034^{\star \star}$ & $-0.040^{\star \star \star}$ & $-0.021^{\star}$ \\
\hline & $(0.081)$ & $(0.027)$ & $(0.054)$ & (0.015) & (0.002) & $(0.011)$ \\
\hline \multirow[t]{2}{*}{ Land } & $0.021^{\star \star}$ & $0.034^{\star \star \star}$ & $0.012^{\star \star}$ & $0.014^{\star \star}$ & $0.021^{* \star *}$ & $0.011^{\star \star \star}$ \\
\hline & (0.010) & $(0.004)$ & $(0.006)$ & (0.005) & (0.003) & $(0.001)$ \\
\hline \multirow[t]{2}{*}{ Transfer } & $-0.257^{\star \star \star}$ & $-0.326^{\star \star \star}$ & $-0.128^{\star \star \star}$ & $-0.045^{\star \star}$ & $-0.051^{\star \star \star *}$ & $-0.043^{\star \star}$ \\
\hline & (0.086) & $(0.027)$ & (0.048) & (0.022) & (0.003) & $(0.021)$ \\
\hline \multirow[t]{2}{*}{ Irrigate } & $1.008^{\star * \star}$ & $1.818^{\star \star \star}$ & $1.210^{\star}$ & $0.194^{\star \star \star}$ & $0.218^{\star * \star}$ & $0.168^{\star \star \star}$ \\
\hline & (0.306) & $(0.384)$ & (0.634) & $(0.060)$ & (0.078) & $(0.031)$ \\
\hline \multirow[t]{2}{*}{ Facility } & $0.491^{\star \star \star}$ & $0.653^{\star \star \star}$ & $-0.172^{\star \star \star}$ & $0.077^{\star \star \star}$ & $0.131^{\star}$ & $0.072^{\star \star \star}$ \\
\hline & (0.158) & (0.209) & (0.022) & $(0.025)$ & $(0.078)$ & (0.019) \\
\hline \multirow[t]{2}{*}{ Terrain } & $2.075^{\star \star \star}$ & $3.388^{\star \star \star}$ & $1.400^{\star \star \star}$ & $0.503^{\star \star \star}$ & $0.516^{\star \star}$ & $0.363^{\star \star \star}$ \\
\hline & $(0.175)$ & $(0.550)$ & (0.335) & (0.089) & (0.008) & (0.089) \\
\hline \multirow[t]{2}{*}{ Constant } & $1.647^{\star \star}$ & 2.251 & $0.621^{\star}$ & $1.238^{\star \star \star}$ & $2.005^{\star \star \star}$ & $0.788^{\star \star}$ \\
\hline & (0.782) & $(0.376)$ & $(0.346)$ & (0.253) & $(0.034)$ & $(0.345)$ \\
\hline
\end{tabular}

${ }^{* * *},{ }^{* *}$, and * denote significance at the 1, 5 and 10\% levels, respectively.

Considering that agricultural operating income involves multiple dependent variables, there will be many endogenous regression models and would take a lot of space to list the test results for the instrumental variables of all endogenous regression models. Therefore, the paper only reports the results of the instrumental variables when the dependent variable is 
agricultural profitability. To ensure the exogeneity of the instrumental variables in the model, they were subjected to overidentification tests. The $p$-value of the transitional identification test is 0.861 , which indicates that the model cannot reject the original hypothesis that the instrumental variables are exogenous. A weak instrumental variable test was further conducted. The value of the F-test statistic of the firststage instrumental variable of the two-stage least squares is 128.37, which meets the standard recommended by Staiger and Stock: that the F-test value is greater than 10 (Hansen, 2000). This shows that there is no weak identification problem of the instrumental variables in the model, and also proves that the level of household savings and level of agricultural mechanization at the village level are not weak instrumental variables (Stock and Yogo, 2005). In addition, considering that the number of instrumental variables in the model is greater than the number of endogenous variables, it is necessary to check whether the instrumental variables are redundant. The results of the redundancy test showed that the $p$-values of household savings level and agricultural mechanization level were 0.001 and 0.000 , respectively, indicating that the null hypothesis-that two instrumental variables were redundant instrumental variables-is rejected.

The above tests show that the two selected tool variables meet the requirements of the model. Although the processes of the Tobit and 2SLS estimation of agricultural mechanization level on total agricultural income are not listed in this paper, the estimation results show that the coefficients of agricultural mechanization level in both the Tobit and 2SLS regressions are greater than the estimated coefficients of OLS, indicating that there is endogeneity and sample selection bias in the model and that the IVTobit results are the most reliable. From columns 1) to (3), it can be seen that for each unit increase in the level of agricultural mechanization, the total agricultural cost, grain crop cost and cash crop cost increase by $0.738,0.548$ and 5.51 units, respectively. The increase in cash crop cost is still the most significant and the estimated coefficient of IVTobit is several times greater than that of OLS. From columns 4) to 6), it can be seen that for each unit increase in the level of agricultural mechanization, the total agricultural output value, grain crop output value and cash crop output value increase by $5.479,8.543$ and 2.521 units, respectively. It is found that the grain crop output increases the most and the estimated IVTobit coefficient also increases significantly. This shows that the sample selection bias and endogeneity problems in the model have been resolved.

The IVTobit model was further used to estimate the impact of the level of agricultural mechanization on agricultural profit and rate of return (Table 5). It can be seen from columns 1)-3) that for each unit increase in the level of agricultural mechanization, the total agricultural profit, grain crop profit and cash crop profit increase by $3.143,5.479$ and 1.694 units, respectively. The increase in grain crop profit is the greatest, and the IVTobit estimation coefficient is also significantly higher than that of OLS. From columns 4) to (6), it can be seen that for every unit increase in the level of agricultural mechanization, the total agricultural rate of return, and those of grain crops and cash crops, increase by $1.215,1.594$ and 0.435 units, respectively, with the greatest effect

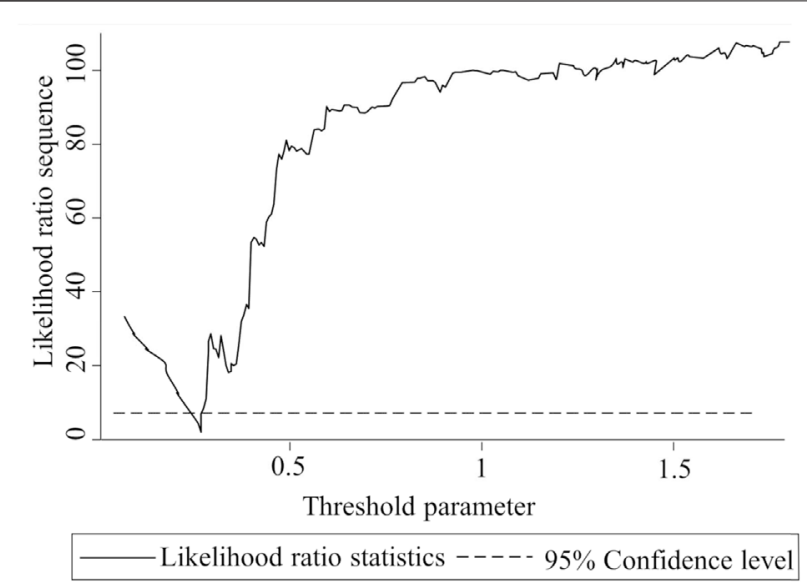

FIGURE 1 | Threshold estimated likelihood ratio.

being on the increase in grain crop rate of return. So far, this paper has largely confirmed that the level of agricultural mechanization increases agricultural profit, more so for grain crops. The possible explanation for this is that grain crops have strong economies of scale and greater availability of suitable agricultural machinery, while cash crops have limited scales of operation and less suitable machinery that is more costly. Therefore, agricultural machinery is likely to increase the production efficiency of grain crops.

3. Heterogeneity Analysis of Agricultural Mechanization Level on Agricultural Operating Income

Due to the relatively high cost of using agricultural machinery, its overall benefits do not always increase with the level of mechanization. When the scale of cultivated land is small, the high cost of using agricultural machinery may weaken its benefits. When farmland reaches a certain scale, the benefits of land-scale operation are sufficient to offset the cost of machinery. Therefore, the effect of agricultural machinery use may vary according to the area of cultivated land. In other words, there is an inflection point in the relationship between farmland area and the influence of mechanization level on operating income. The impact is small before the inflection point and larger after it. The key to solving the above problem is to determine the inflection point and then test the heterogeneity effect before and after the inflection point. The threshold estimation method can accurately determine the threshold value and, considering that the data used in this article are cross-sectional, Hansen's cross-sectional data threshold estimation method can be used to determine the threshold value. This can be combined with graphical analysis to show the trend in inflection point changes (Hansen, 2000).

\subsection{Threshold Analysis}

In this study, the area of farmland was taken as the threshold variable. The threshold effect model estimated a threshold value of $0.28 \mathrm{hm}^{2}$. Then, the LM test method was used to verify whether the model had a threshold effect. The LM statistic was 218.97 after 
TABLE 6 | Threshold robustness test.

\begin{tabular}{|c|c|c|c|c|c|}
\hline Estimated variables & $\begin{array}{c}\text { Only farmland } \\
\text { area }\end{array}$ & $\begin{array}{c}\text { Farmland area } \\
+ \text { Basic } \\
\text { family characteristics }\end{array}$ & $\begin{array}{l}\text { Farmland area } \\
+ \text { production } \\
\text { and operation } \\
\text { characteristics }\end{array}$ & $\begin{array}{l}\text { Farmland area } \\
+ \text { control } \\
\text { variables other } \\
\text { than area } \\
\text { variables }\end{array}$ & $\begin{array}{l}\text { Farmland area } \\
+ \text { all } \\
\text { control variables }\end{array}$ \\
\hline Threshold & 0.265 & 0.266 & 0.275 & 0.279 & 0.280 \\
\hline$p$-value & 0.015 & 0.004 & 0.003 & 0.001 & 0.000 \\
\hline
\end{tabular}

TABLE 7 | Estimation of the threshold effect of agricultural mechanization level on agricultural profit.

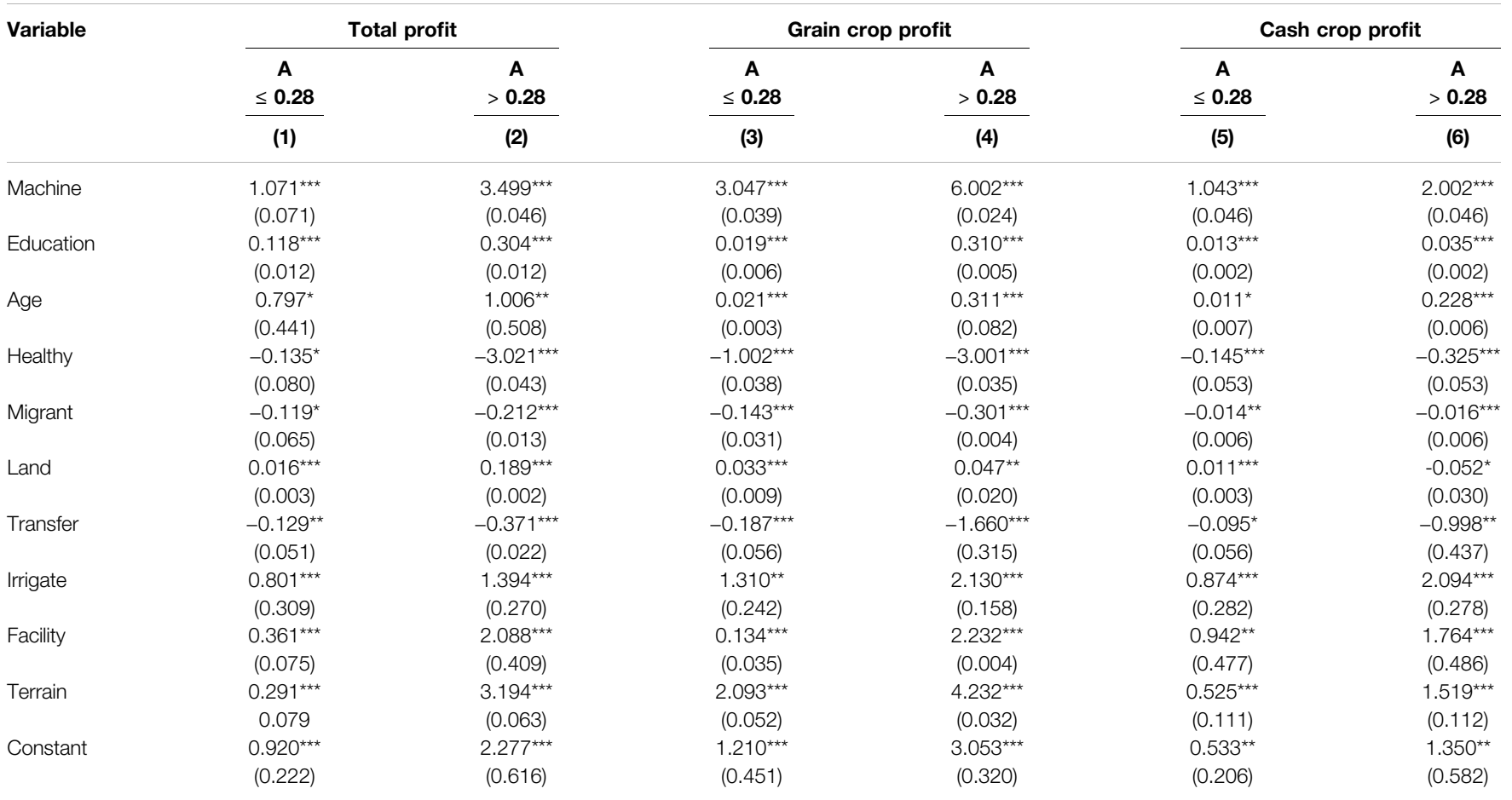

***, **, and * denote significance at the 1,5 and 10\% levels, respectively.

500 bootstraps with a $p$-value of 0.000 , indicating that there was indeed a threshold effect in the model. In addition, a graphical representation of the inflection point changes is shown in Figure 1. The inflection point of the likelihood rate series curve is obvious at $0.28 \mathrm{hm}^{2}$, where the likelihood rate is far below the $95 \%$ threshold (dashed line in the figure), so it can be judged that $0.28 \mathrm{hm}^{2}$ is the threshold value of the model.

To ensure the robustness of the threshold estimation, control variables were gradually introduced into the model. Their validity was verified by comparing the threshold values estimated by different models. The result is shown in Table 6 . The control variables were divided into three categories: basic household characteristics, production and operation characteristics, and regional variables. The basic household characteristics variables included education level per household member, average age of family labour force, and percentage of unhealthy people, while the production and operation characteristics variables included the average working hours of migrant workers, area of farmland, transfer-out area of farmland, proportion of farmland irrigation, and proportion of greenhouse area. The control variables were added into the threshold model in batches and it was found that with increases in the control variables, the threshold value tended to be more stable and the $p$-value became more significant. Finally, the threshold value of cultivated land area estimated by the threshold effect model was $0.28 \mathrm{hm}^{2}$. Therefore, it can be considered that the estimated threshold value is a credible "convergence point" when all control variables are added to the model.

\subsection{Estimation of the Threshold Effect of the Level of Agricultural Mechanization on Agricultural Income}

After determining the threshold value, the sample was divided into two subsamples according to the threshold value $(\leq 0.28$ and $>0.28$ ) in order to examine the effect of the level of agricultural 
TABLE 8 | Estimation of the threshold effect of agricultural mechanization level on the rate of return.

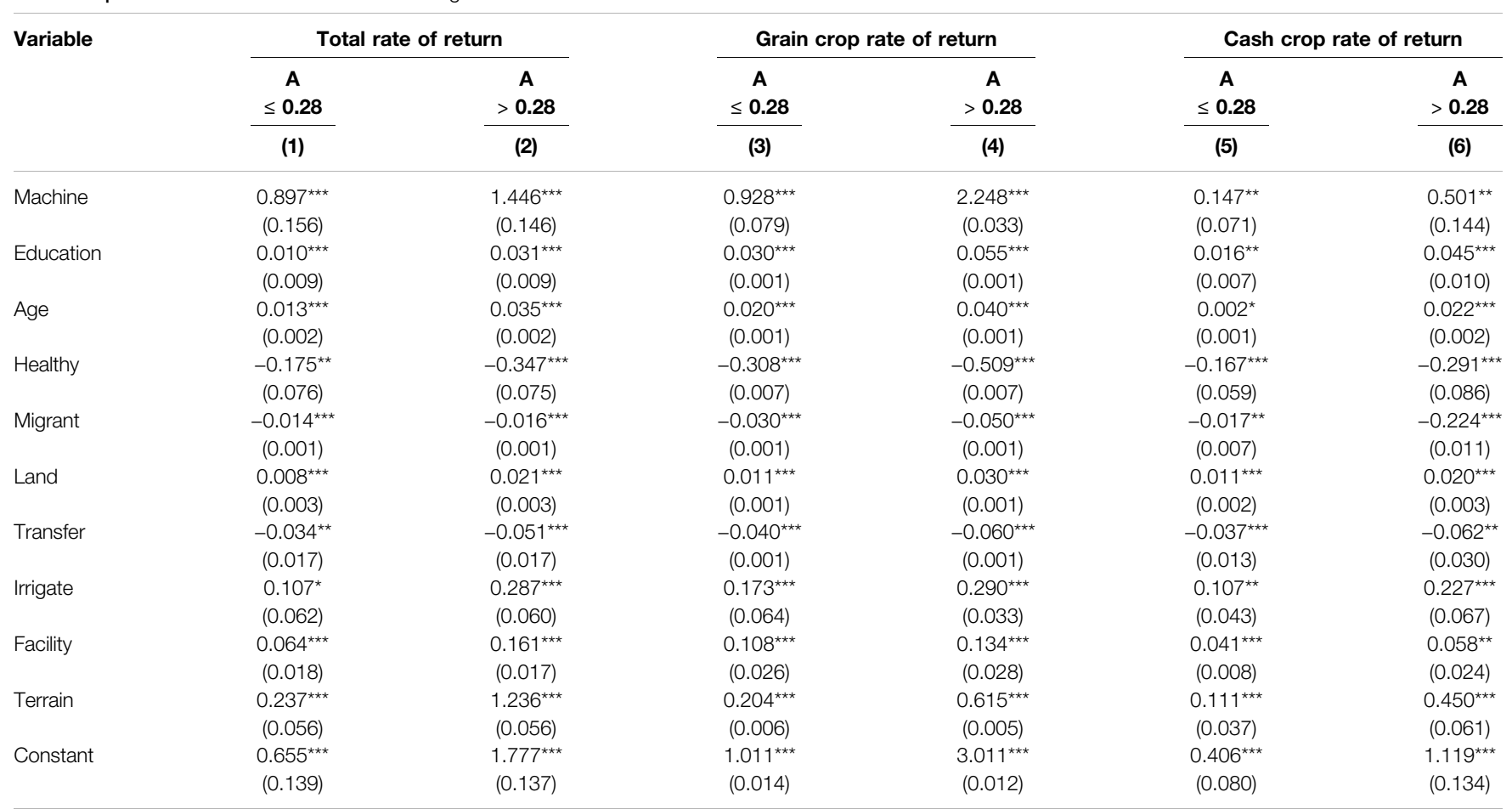

***, **, and ${ }^{*}$ denote significance at the 1, 5 and $10 \%$ levels, respectively.

mechanization on the agricultural profit and rate of return before and after the threshold value. The results of the IVTobit model are shown in Tables 7, 8. Table 7 shows the estimate of the threshold effect of the level of mechanization on the profits of various crops. From the total agricultural profit model, the regression coefficients of mechanization level before and after the threshold are different. For each unit increase in mechanization level, the total profit before and after the threshold increase significantly, by 1.071 and 4.1 units, respectively. This indicates that increasing the level of agricultural mechanization will increase the total income of farmers with large operating areas, which basically confirms the validity of the threshold value. From the perspective of the profit of grain crops, each unit increase in the level of mechanization significantly increases the profit by 3.047 and 6.002 units before and after the threshold, respectively. For cash crop profit, each unit increase in the level of mechanization significantly increases the profit by 1.043 and 2.002 units before and after the threshold, respectively.

Table 8 shows the estimated threshold effect of agricultural mechanization level on the rate of return of various crops. For the model of the total agricultural rate of return, each unit increase in the level of mechanization significantly increases the total agricultural rate of return before and after the threshold by 0.897 and 1.446 units, respectively. This indicates that machinery is more conducive to increasing the total agricultural rate of return after the threshold. For grain crops, each unit increase in the level of mechanization significantly increases the rate of return by 0.928 and 2.248 units before and after the threshold, respectively. For cash crops, each unit increase in the level of mechanization significantly increases the rate of return before and after the threshold by 0.147 and 0.501 units, respectively. These coefficients are smaller than those of grain crops before and after the threshold. It can be seen that the level of mechanization has heterogeneous effects on operating income. Firstly, in terms of the scale of household farming, the use of machinery is more likely to increase the profit and rate of return of farmers with larger farms. The threshold value of the operating scale tested in this paper is $0.28 \mathrm{hm}^{2}$; in other words, farmers who exceed the operating threshold area will have higher incomes. Second, grain machinery is better developed and more available and cost-effective. Therefore, it can more easily increase the profit and rate of return of grain crops.

4. Mechanism of the Effect of Agricultural Mechanization Level on Agricultural Operating Income

The above section confirmed that the level of agricultural mechanization indeed improves agricultural operating income. This section analyses the mechanisms underlying this effect. Table 9 shows the results of the mechanism of action test. Considering the simplicity of the test process, only the total agricultural rate of return was selected as the target variable of agricultural operating income in the model. In general, machinery can effectively improve the yield and quality of crops and this paper also analyses these two paths. The first is the factor-intensification path, in which the use of agricultural machinery can effectively increase labour productivity and land 
TABLE 9 | Mechanism of the effect of agricultural mechanization level on profit.

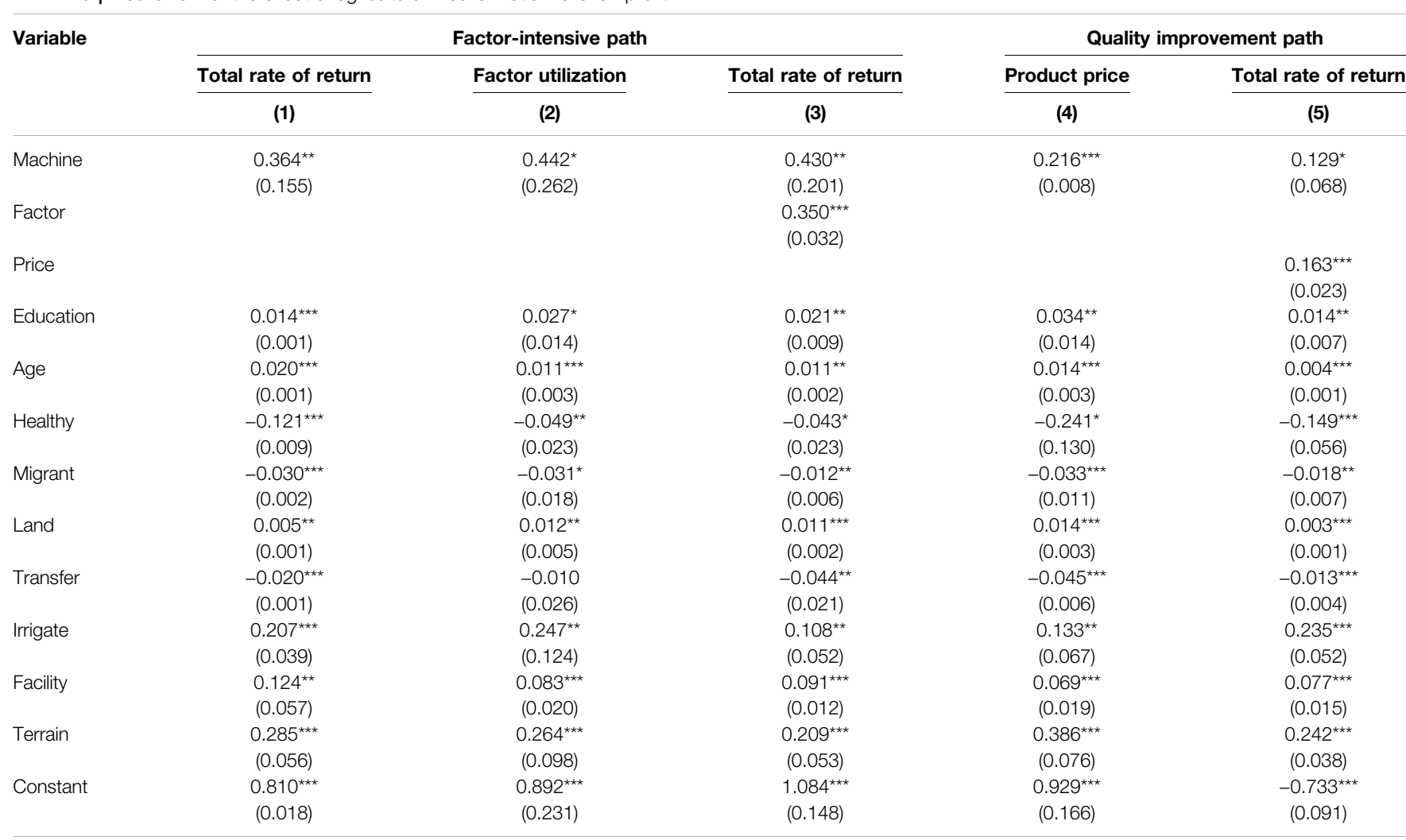

${ }^{* * *},{ }^{* *}$, and * denote significance at the 1, 5 and 10\% levels, respectively.

productivity. Obtaining more agricultural products will spread out the cost of agricultural production, thus enhancing the utilization rate of agricultural production factors and increasing income. Therefore, the first mechanism variable chosen is the factor utilization rate, using agricultural output divided by agricultural cost; the second is the quality improvement path. The use of machinery can effectively increase the degree of standardization of agricultural production. Standardized production improves the quality of agricultural products and, hence, their sales price and resulting income. Therefore, the second mechanism variable chosen was the price of agricultural products. Considering the wide variety of agricultural products, this paper uses the average price of agricultural products for measurement.

From the factor-intensification path test, column 2) in Table 9 shows that the level of mechanization has a significant positive effect on the utilization rate of agricultural factors. Column 3) shows that the utilization rate has a significant positive effect on the total agricultural rate of return. Since the estimated coefficients of mechanization level and the utilization rate of agricultural factors in columns 1) to 3) pass the significance test, it indicates that factor utilization rate plays a partial intermediary role in the model, with a $28.8 \%$ mediation effect. It also shows that the effect of mechanization in increasing yield improves the utilization rate of agricultural factors, thus improving income. The quality improvement path test in column 4) shows that the level of mechanization significantly improves the quality of agricultural products. After controlling for the level of mechanization, the price of agricultural products still has a significant positive impact on the total income. The estimated coefficients of the level of mechanization and price of agricultural products in columns 4) and 5) both pass the significance test, indicating that the price of agricultural products plays a partially mediating role in the model with an effect size of $27.4 \%$. This also indicates that the effect of mechanization level on improving the quality of agricultural products increases their price and, thus, income.

\section{CONCLUSIONS AND POLICY INSIGHT}

Improving agricultural operating efficiency is not only an effective means to increase farmers' income and agricultural efficiency, but is also the essence of the Rural Revitalization Strategy. Based on a field survey of 1,116 farmers in Hubei Province in 2018, this paper analysed the impact of the level of agricultural mechanization on agricultural production and income by using a sample-modified endogenous consolidation model (IVTobit) and threshold-effect model. The results show that 1) the level of agricultural mechanization has a significant positive impact on the production cost, output value, income and yield of all kinds of crops. For every unit increase in the level of mechanization, the costs of all crops, grain crops and cash crops increase by $0.738,0.548$ and 5.51 units, the output values increase 
by $5.479,8.423$ and 2.521 units, the incomes increase by 3.143 , 5.479 and 1.694 units, and the rate of return rise by $1.215,1.594$ and 0.435 units, respectively. 2) From the perspective of heterogeneity analysis, there is an obvious threshold effect of mechanization level on income, with a threshold value of 0.28 ha. Subject to scale effects, the mechanization level has a greater impact on the agricultural operation benefits of various crops after the threshold. 3) The action mechanism test showed that mechanization can increase income via the factor intensification path and quality improvement path. The partial mediating effects of the factor utilization rate and agricultural product price on the agricultural total return rate are 28.8 and $27.4 \%$, respectively.

To sum up, this paper found that agricultural mechanization can effectively improve agricultural income. Increasing income is a basic requirement for the high-quality development of agriculture. We should give full play to the positive role of agricultural machinery in increasing agricultural efficiency and farmers' income. Improving the level of mechanization is also an effective way to promote agricultural modernization. First, we should continue to increase subsidies for the purchase of agricultural machinery, improve and optimize the levels of agricultural machinery and equipment, increase subsidies for machines and tools to overcome weak links in grain production and cropping in hilly and mountainous areas, promote green intelligent agricultural machinery, promote the scrapping and upgrading of agricultural machinery, and transform farmland to make it suitable for mechanization. Second, we should accelerate the research and development and popularization of machinery related to major cash crops, reduce the usage cost of cash crop machinery, and gradually mechanize the whole process of cash cropping, from sowing to field management to harvesting. Third, we should promote the development of socialized service organizations for agricultural machinery operations, improve the standard system of socialized service for agriculture, accelerate the improvement of agricultural socialization service levels, form a new pattern of diversified and shared socialized services for agriculture, and improve the utilization rate of agricultural machinery and level of mechanized operation. Fourth, we should give full play to agricultural cooperatives in the promotion of mechanization, deepen the integration of agricultural machinery and agronomy, vigorously promote advanced and second-round exams, promote intelligent, green and novel agricultural machines and tools, improve farmers' ability to apply new agricultural machinery technologies and new machines and

\section{REFERENCES}

Aslan, S. T. A., Gundogdu, K. S., Yaslioglu, E., Kirmikil, M., and Arici, I. (2007). Personal, Physical and Socioeconomic Factors Affecting Farmers' Adoption of Land Consolidation. Span J. Agric. Res. 5, 204-213. doi:10.5424/sjar/2007052-240

Berdnikova, L. N. (2018). The Safety of Working with the Equipment for Protecting Plants from Pests and Diseases Processing by Toxic Chemicals on Experimental Plots. Bull. KSAU 1, 114-120. doi:10.1007/978-94-007-6728-7-17-1

Cadr, D., and Krueger, A. B. (1996). School Resources and Student Out-Comes: An Overview of the Literature and New Evidence from North and South Carolina. Gen. Inf. 10, 31-50. doi:10.1257/jep.10.4.31 tools, and provide strong scientific and technological support for agricultural transformation and upgrades, and quality and efficiency improvement.

This study also has some limitations. Subject to the sample size, this paper did not subdivide the varieties of grain crops and cash crops. The level of mechanization may have different effects on the operating incomes of different grain and cash crops. However, this paper also has some progress, that is, it avoids analyzing only the total cost or total income of agriculture in previous studies, and considers the threshold effect of agricultural machinery use, which is more meaningful for analyzing the mechanism of action and policy making. In addition, this paper did not investigate the impacts of different agricultural machinery operations on income and it may be conducive to policy-making to explore these impacts. Therefore, survey data with a larger sample size is needed to analyse the above problems in future.

\section{DATA AVAILABILITY STATEMENT}

The original contributions presented in the study are included in the article/supplementary material, further inquiries can be directed to the corresponding author.

\section{AUTHOR CONTRIBUTIONS}

PJ conceived of the idea for this study. PJ and ZZ conducted the statistical analysis. LD contributed to the final write-up.

\section{FUNDING}

This research was funded by the National Natural Science Foundation of China (No. 72063012), 2020 ministry of Education Humanities and Social Science Research General Project (No. 20YJC790103) and 2021 Science and Technology Research Project of Jiangxi Provincial Department of Education (No. GJJ210282).

\section{ACKNOWLEDGMENTS}

The valuable comments and suggestions of editors and reviewers are gratefully acknowledged.

Cai, R., Chen, W., and Zhu, X. (2015). Cost Benefit: Internal Cause and Key to Solve the Nongrain Transfer of Cultivated Land. Rural Econ. 7, 44-49.

Chen, S. S., and Zhang, X. Q. (2021). Agriculture Green and High-Quality Development of Fujian Province under New Era. Sci. Tech. Mana. Res. 18, 96-104. doi:10.3969/j. issn.1000-7695.2021.18.013

Chen, Y., Xie, B., and Wei, C. (2014). The Difference of Farm Land Income under the Background of Endogenous and Exogenous farmland Circulation Modes and its Influence on Farmers' Income--A Case of Jingyuan county,Baiyin City. J. Arid Land Res. Environ. 28, 27-32. doi:10.13448/j. cnki.jalre.2014.09.024

Chen, F. (2015). Research on the Threshold Effect of Cultivated Land Scale Used in Agricultural Production Technology. Res. Financi. Econ. Issues 6, 78-86. 
Chen, J. W. (2019). The Influence of the New Farmer's Professional Identity on the Income of Agricultural Management: Based on the Analysis of Tendency Value Matching Method. Dong Yue Tribune 40, 162-173. doi:10.15981/j.cnki. dongyueluncong.2019.11.017

Deng, X., Yan, Z., Xu, D., and Qi, Y. (2020). Land Registration, Adjustment Experience, and Agricultural Machinery Adoption: Empirical Analysis from Rural China. Land 9, 89. doi:10.3390/land9030089

Gao, M., and Wang, Y. (2021). Influence of China's Agricultural Subsidy Policy on Food Security and Reform Direction. J. South. Chin. Agric. Univ. 20, 14-26. doi:10.7671/j.issn.1672-0202.2021.05.002

Hansen, B. E. (2000). Sample Splitting and Threshold Estimation. Econometrica 68, 575-603. doi:10.1111/1468-0262.00124

He, L. X., Nan, Y. Q., and Zhang, Z. G. (2016). Will Agricultural Labor Force Aging lead to the Decrease of Household's Agricultural Earnings? Based on the Perspective of Village Public Goods Supply. J. Nanjing Agric. Univ. 16, $105-116$.

He, J., Li, H. W., Chen, H. T., Lu, C. Y., and Wang, Q. J. (2018). Research Progress of Conservation Tillage Technology and Machinery. Trans. Chin. Soc. Agric. Machinery. 49, 1-19. doi:10.6041/j.issn.1000-1298.2018.04.001

Hu, Y., and Zhang, Z. H. (2018). The Impact of Agricultural Machinery Service on Technical Efficiency of Wheat Production. Chin. Rural Econ. 5, 68-83.

Huang, Z. (2021). Exploring the Way to Deal with Climate Change and Agricultural High-Quality Transformation and Development under the New Pattern of Double Cycle. J. Northwest. A. F Univ. 21, 161. doi:10.36012/sde. vli2.218

Ji, Z.-X., Wang, X.-L., Li, L., Guan, X.-K., Yu, L., and Xu, Y.-Q. (2021). The Evolution of Cultivated Land Utilization Efficiency and its Influencing Factors in Nanyang Basin. J. Nat. Resour. 36, 688-701. doi:10.31497/zrzyxb.20210312

Jiang, Y., and Zhang, X. (2017). Analysis on the Evolution Power of Agricultural Modernization with Chinese Characteristics. Rural Econ. 2, 86-92.

Lei, X. K., Luo, M. Z., and Liu, Z. Y. (2021). Internet Use, Risk Preference and the Production and Management Benefits for New-type Professional Farmers. J. Arid Land Res. Environ. 35, 28-33. doi:10.13448/j.cnki.jalre.2021.124

Li, Q., Amjath-Babu, T. S., and Zander, P. (2016). Role of Capitals and Capabilities in Ensuring Economic Resilience of Land Conservation Efforts: A Case Study of the Grain for green Project in China's Loess Hills. Ecol. Indicators 71, 636-644. doi:10.1016/j.ecolind.2016.07.027

Li, T., Yu, W., Baležentis, T., Zhu, J., and Ji, Y. (2017). Rural Demographic Change, Rising Wages and the Restructuring of Chinese Agriculture. China Agric. Econ. Rev. 9, 478-503. doi:10.1108/caer-02-2016-0025

Li, X. F., Huang, D., and Wu, L. P. (2019). Study on Grain Harvest Losses of Different Scales of Farms -- Empirical Analysis Based on 3251 Farmers in China. China Soft Sci. 8, 184-192. doi:10.3969/j.issn.1002-9753.2019.08.016

Li, F. J., Xu, D. Y., Wu, P., Yue, T., Zhu, M., Li, C. Y., et al. (2021). Effects of Mechanical Tillage and Sowing Methods on Photosynthetic Production and Yield of Wheat in rice Stubble. Trans. Chin. Soci. Agric. Machinery. 5, 41-49. doi:10.11975/j.issn.1002-6819.2021.05.005

Liu, T. S., and Wu, G. (2019). Benefit Loss of farmland Resource Misallocation: An Empirical Analysis Based on Farmers' Willingness to Transfer farmland. J. Nanjing Agric. Univ. 19, 107-118. doi:10.19714/j.cnki.1671-7465.2019.0091

Liu, H. H., and Zhou, H. (2018). Analysis on Farmers' Selection Behavior of Mechanized-Transplantation and its Influencing Factors: Based on the Perspective of Link Cost and Survey Data of Main rice Producing Area in Jiangsu. J. Hunan Agric. Univ. 19, 32-37. doi:10.13331/j.cnki.jhau(ss).2018. 01.005

Liu, S., Xie, F., Zhang, H., and Guo, S. (2014). Influences on Rural Migrant Workers' Selection of Employment Location in the Mountainous and upland Areas of Sichuan, China. J. Rural Stud. 33, 71-81. doi:10.1016/j.jrurstud.2013.11.001

Liu, T., Cui, Y. Z., and Huo, J. J. (2021). Research on Allocation Efficiency Measurement and Spatial Agglomeration Effect of Agricultural Machinery Equipment under High-Quality Development Background. J. Chin. Agric. Mechan. 5, 123-128. doi:10.13733/j.jcam.issn.2095-5553.2021.05.17

Liu, H. K. (2020). Reflection and Reconstruction of Income Distribution System of Household Contract Management. Com. Res. 4, 139-145. doi:10.13902/j.cnki. syyj.2020.04.016

Lu, H., and Hu, H. (2015). Does Land Fragmentation Increase Agricultural Production Costs? --A Microscopic Investigation from Jiangsu Province. Econ. Rev. 5, 129-140. doi:10.19361/j.er.2015.05.010
Lu, P. (2014). Exploring the Bottleneck and the Way Out of China's Sustainable Agricultural Development. Theor. Invest. 6, 85-88. doi:10.16354/j.cnki.231013/d.2014.06.036

Luo, M. Z., and Qiu, H. L. (2021). Agricultural Machinery Socialization Service Adoption, Endowment Difference and Alleviation of Rural Economic Relative Poverty. South. China J. Econ. 2, 1-18. doi:10.19592/j.cnki.scje.381027

Luo, B. (2020). Small Farmers and Modern Agriculture. Issues Agric. Econ. 1, 28. doi:10.13246/j.cnki.iae.2020.01.003

Nam, K., Suk, S. D., and Byeong-il, A. (2021). The Empirical Analysis of Production Cost Reduction Effects from the Agricultural Machinery Rental Policy. J. Rural Dev. 44, 51-78. doi:10.36464/jrd.2021.44.2.003

Ning, Y. W., Zhang, H., and Zhang, Y. C. (2018). North and South Differencee of rice Planting Behavior in Jiangsu Province and its Influences on Input of Chemical Fertilizer: A Case Study in Suzhou and Yancheng. Jiangsu J. Agric. Sci. 3, 533-539. doi:10.3969/j.issn.1000-4440.2018.03.008

Peng, C., and Zhang, C. (2020). Assessment of Agricultural Mechanization on Farmers' Grain Aggregated Production Efficiency. J. South. China Agric. Univ. 19, 93-102. doi:10.7671/j.issn.1672-0202.2020.05.009

Peng, L., Liu, S., and Sun, L. (2016). Spatial-Temporal Changes of Rurality Driven by Urbanization and Industrialization: A Case Study of the Three Gorges Reservoir Area in Chongqing, China. Habitat Int. 51, 124-132. doi:10.1016/j. habitatint.2015.10.021

Peng, J. Q., Wu, H. T., Tan, C., and Li, M. D. (2019). Influence of Agricultural Mechanization Level on Farmers' Marketization: The Threshold Effect of Agricultural Land Based on Per Capita Basic Needs. J. Chin. Agric. Univ. 7, 167-180. doi:10.11841/j.issn.1007-4333.2019.07.20

Peng, J. Q., Wu, H. T., Cheng, W. T., and Jiang, F. (2020). Study on the Effect of Mechanization on Farmer's Planting Structure--Estimation Method Based on Ivgmm and Ivtobit. Chin. J. Agric. Res. Reg. Plann. 41, 55-65. doi:10.7621/ cjarrp.1005-9121.20200108

Peng, J., Chen, J., Su, C., Wu, Z., Yang, L., and Liu, W. (2021a). Will Land Circulation Sway "Grain Orientation"? The Impact of Rural Land Circulation on Farmers' Agricultural Planting Structures. PLOS ONE 16, e0253158. doi:10. 1371/journal.pone. 0253158

Peng, J. Q., Wu, H. T., and Wang, W. (2021b). The Influence of Agricultural Mechanization Level on Farmers' Production of Staple Food. Chin. J. Agric. Res. Reg. Plann. 42, 51-59. doi:10.7621/cjarrp.1005-9121.20210107

Peng, J. Q., and Zhang, L. G. (2020). Influence of Agricultural Machinery on the Planting Area of Farmers' Main Grains. J. Chin. Agric. Univ. 9, 227-238. doi:10. 11841/j.issn.1007-4333.2020.09.22

Qu, X., Kojima, D., Nishihara, Y., Wu, L.-P., and Ando, M. (2021). Can Harvest Outsourcing Services Reduce Field Harvest Losses of rice in China? J. Integr. Agric. 20, 1396-1406. doi:10.1016/S2095-3119(20)63263-4

Ragasa, C., and Chapoto, A. (2017). Moving in the Right Direction? The Role of Price Subsidies in Fertilizer Use and maize Productivity in Ghana. Food Security 9, 329-353. doi:10.1007/s12571-017-0661-7

She, M. L., Weng, S. B., and Li, Y. (2013). Cost Benefit Analysis of Rural Land System Innovation -- Taking "Two Points and Two Exchanges" in Jiaxing City, Zhejiang Province as an Example. Issues Agric. Econ. 34, 33-39. doi:10.13246/j. cnki.iae.2013.03.007

Staiger, D., and Stock, J. H. (1997). Instrumental Variables Regression with Weak Instruments. Econometrica 65, 557-586. doi:10.2307/2171753

Stock, J. H., and Yogo, M. (2005). Testing for Weak Instruments in Linear IV Regression. Cambridge: Cambridge University Press. doi:10.1017/ CBO9780511614491.006

Tang, L., Liu, Q., Yang, W., and Wang, J. (2018). Do agricultural Services Contribute to Cost Saving? Evidence from Chinese rice Farmers. Chin. Agric. Econ. Rev. 10, 323-337. doi:10.1108/caer-06-2016-0082

Tian, X., Yi, F., and Yu, X. (2020). Rising Cost of Labor and Transformations in Grain Production in China. China Agric. Econ. Rev. 12, 158-172. doi:10.1108/ CAER-04-2018-0067

Wang, X., and Tan, S. (2020). Cost-Efficiency Analysis of Rice-Crayfish Integrated Land Operation Mode Based on Non-Homogeneous DEA. China Land Sci. 34, 56-63. doi:10.11994/zgtdkx.20191225.105326

Xiao, T. Q., He, C. X., Chen, Q. M., Chen, Y. S., Cao, G. Q., and Cui, S. Y. (2015). Cost-Benefit Analysis of Vegetable Production Based on Agricultural Mechanized Production. Trans. Chin. Soci. Agric. Machinery. 46, 75-82. doi:10.6041/j.issn.1000-1298.2015.05.012 
Xu, D., and Song, W. (2021). Research on the Evaluation of Green Development of Agriculture in the Perspective of Rural Revitalization. Study Explo 3, 130-136. doi:10.36922/ssr.v3i5.1261

Xu, D., Deng, X., Guo, S., and Liu, S. (2019a). Sensitivity of Livelihood Strategy to Livelihood Capital: An Empirical Investigation Using Nationally Representative Survey Data from Rural China. Soc. Indic. Res. 144, 113-131. doi:10.1007/ s11205-018-2037-6

Xu, D., Deng, X., Huang, K., Liu, Y., Yong, Z., and Liu, S. (2019b). Relationships between Labor Migration and Cropland Abandonment in Rural China from the Perspective of Village Types. Land Use Policy 88, 104164. doi:10.1016/j. landusepol.2019.104164

Xu, D., Ma, Z., Deng, X., Liu, Y., Huang, K., Zhou, W., et al. (2020). Relationships between Land Management Scale and Livelihood Strategy Selection of Rural Households in China from the Perspective of Family Life Cycle. Land 9, 11. doi:10.3390/land9010011

Yang, J., and Liu, X. Y. (2021). The Impact of Agricultural Planting Structure Change on Production Efficiency in China-Based on the Perspective of Specialized Division of Labor. J. Huazhong Univ. Sci. Tech. (Social Sci. Edition) 35, 64-73. doi:10.19648/j. cnki.jhustss1980.2021.04.08

Yang, H., Huang, K., Deng, X., and Xu, D. (2021). Livelihood Capital and Land Transfer of Different Types of Farmers: Evidence from Panel Data in Sichuan Province, China. Land 10, 532. doi:10.3390/land10050532

Yao, C. S., Hou, F. G., and Chen, H. Y. (2021). Logical Relation and its Policy Implications between Agricultural Mechanization and Food Security: Based on a Contrastive Study of the Cost and Benefit of Three Main Grain Crops between China and the United States. J. Chin. Agri. Mechan. 42, 1-8. doi:10.13733/j. jcam.issn.2095-5553.2021.01.001

Yao, J. L. (2009). Relationship of Agriculture Mechanization Development and Cost Decrement of Three Main Grain Crops. J. Agric. Mechan. Res. 31, 24-27. doi:10.3969/j.issn.1003-188X.2009.04.007
Zeng, F., and Li, F. (2015). Estimation of Cost Saving Effect of Agricultural Infrastructure on Grain Production--Based on Seemingly Unrelated Regression Method. Chin. Rural Econ. 6, 4-12.

Zhang, C., Chang, Q., and Huo, X. (2018). Can the Moderate-Scale Management Really Reduce the Production Costs of Agricultural Products? - an Empirical Analysis Based on 661 Shanxi Apple Farmers. J. Agrotechnical Econ. 10, 26-35. doi:10.3390/su10124525

Zhou, Y. H., Li, W. Q., Zhang, M., Pan, R. G., and Zou, J. Q. (2017). Analysis of China's Sorghum Trade and Production Cost of Sorghum in the United States. Acta Agric. Zhejiangensis. 29, 1589-1594. doi:10.3969/j.issn.1004-1524.2017.09.24

Zhou, Y. B., He, K., Zhang, J. B., and Cheng, L. L. (2019). Growth, Structural and Distribution Effects of Agricultural Mechanization on Farmers' Income. J. Sichuan Agric. Univ. 37, 723-733. doi:10.16036/j.issn.1000-2650.2019.05.018

Conflict of Interest: The authors declare that the research was conducted in the absence of any commercial or financial relationships that could be construed as a potential conflict of interest.

Publisher's Note: All claims expressed in this article are solely those of the authors and do not necessarily represent those of their affiliated organizations, or those of the publisher, the editors and the reviewers. Any product that may be evaluated in this article, or claim that may be made by its manufacturer, is not guaranteed or endorsed by the publisher.

Copyright (c) 2022 Peng, Zhao and Liu. This is an open-access article distributed under the terms of the Creative Commons Attribution License (CC BY). The use, distribution or reproduction in other forums is permitted, provided the original author(s) and the copyright owner(s) are credited and that the original publication in this journal is cited, in accordance with accepted academic practice. No use, distribution or reproduction is permitted which does not comply with these terms. 